Check for updates

The BMJ

hmacdonald@bmi.com Follow Helen on Twitter@drhelmac

Cite this as: $B M J 2021 ; 375: \mathrm{n} 3082$

http://dx.doi.org/10.1136/bmj.n3082

Published: 16 December 2021

\section{CHRISTMAS 2021}

\section{Pure imagination}

\section{Helen Macdonald clinical editor}

These are extraordinary times. Although the scenes reflected in this year's Christmas baubles might be distorted or dulled by the pandemic, we hope to provide some comfort, sparkle, and space to imagine a better future. Inside this issue you'll find David Robertson and Peter Doshi wondering how we'll know that the pandemic has ended (doi:10.1136/bmj-2021068094), ${ }^{1}$ while Agnes Arnold-Forster conjures utopias from the aftermath of cataclysmic events (doi:10.1136/bmj.n2892), ${ }^{2}$ encouraging readers to think big to create a better world.

Readers in need of escapism can ponder the lessons learnt from head injuries in nursery rhyme characters (doi:10.1136/bmj-2021-068256) ${ }^{3}$ or the health of ageing superheroes (doi:10.1136/bmj-2021-068001). ${ }^{4}$ Feast your eyes on a traditional Christmas table and spot the toxic seasonal botanicals (doi:10.1136/bmj-2021066995), 5 click the QR codes to hear what gout and other conditions might sound like (doi:10.1136/bmj2021-068240), ${ }^{6}$ and read Greta Bauer's wildly duplicitous scheme for publishing poor research (doi:10.1136/bmj-2021-067350). ${ }^{7}$ Her infographic might help you evaluate whether second to fourth finger digit ratio is associated with luck when playing poker (doi:10.1136/bmj-2021-067849) ${ }^{8}$ or whether the density of heavy metal bands in a population is correlated with death (doi:10.1136/bmj-2021-067633). ${ }^{9}$ Juan Franco and Santiago Esteban demystify chance findings and artificial intelligence (doi:10.1136/bmj.n2915). ${ }^{10}$

Behind data are people, and empathy is as important in clinical research as in medicine. Among some trial participants, hope is treasured (doi:10.1136/bmj-2021066851), ${ }^{11}$ but Christmas cards from their trial organisers proved less so (doi:10.1136/bmj-2021067742). ${ }^{12}$ We can provide better care if we put ourselves in colleagues' shoes, as a GP and a consultant learnt when they traded places (doi:10.1136/bmj.n3005), ${ }^{13}$ as did other clinicians who reflect here on their "covid careers" (doi:10.1136/bmj.n2762). ${ }^{14}$ Those redeployed to intensive care might have found it a "smidge" easier to navigate using James Hodgetts and colleagues' slang dictionary for new starters-a reminder that clear language can make medicine safer and more inclusive (doi:10.1136/bmj-2021-067900). ${ }^{15}$

Many clinicians want to change lives for the better, especially those working in Afghanistan with Médecins Sans Frontières, which is where your donations to The BMJ's annual appeal will go this year (doi:10.1136/bmj.n3004). ${ }^{16}$

Sometimes you have to think outside the box to change the world. The hip hop artist Logic released a song about mental health struggles, using a US helpline number for its title. Social media activity around the song saw increased calls to the number, which were associated with a reduction in suicide (doi:10.1136/bmj-2021-067726). ${ }^{17}$ His song of hope illustrates how the creative arts can support people in mental distress (doi:10.1136/bmj.n2964). ${ }^{18}$

Fiona Godlee talks about her time as editor in chief of The BMJ as she steps down after more than 16 years (doi:10.1136/bmj.n2986), ${ }^{19}$ and you can hear the full interview on our podcast (https://bit.ly/BMJInterview). Thanks, Fi, for your vision and leadership.

Lastly, few things are as simple, seasonal, or wonderful as giving and receiving thanks (doi:10.1136/bmj.n2816). ${ }^{20}$ Join our campaign on Twitter to thank the people who have been supportive through the pandemic (\#bmjcovidthanks): this may be the seasonal boost healthcare professionals need most as they prepare for what 2022 will bring.

Robertson D, Doshi P. The end of the pandemic will not be televised. BMJ 2021;375:e068094doi: 10.1136/bmj-2021-068094

2 Arnold-Forster A. Building utopia from disaster: could the pandemic show a way to better healthcare? An essay by Agnes Arnold-Forster. BMJ 2021;375:n2892. doi: 10.1136/bmj.n2892 .

3 Patton DA. We all fall down: head injuries in nursery rhyme characters. BMJ 2021;375:e068256. doi: 10.1136/bmj-2021-068256

4 Fox ST, Reid N, Tornvall I, Weerasekera S, Gordon E, Hubbard RE. Anticipating the ageing trajectories of superheroes in the Marvel cinematic universe. BM/2021;375:e068001doi: 10.1136/bmj-2021-068001 .

5 Huntington GR, Byrne ML. The holly and the ivy: a festive platter of plant hazards. BMJ2021;375:BMJ-2021-066995. doi: 10.1136/bmi-2021-066995

$6 \quad$ O'Neill D. Listening to illness: hearing gout through music. BMJ 2021;375:e068240doi: 10.1136/bmj-2021-068240 .

7 Bauer GR. Biased Outcome reporting Guidelines for Underwhelming Studies (BOGUS) statement and checklist. BM/2021;375:e067350. doi: 10.1136/bmj-2021-067350 pmid: 34893508

8 Smoliga JM, Fogaca LK, Siplon JS, Goldburt AA, Jakobs F. Giving science the finger-is the second-to-fourth digit ratio (2D:4D) a biomarker of good luck? A cross sectional study. BM/2021;375:e067849. doi: 10.1136/bmj-2021-067849

9 Martikainen P, Korhonen K, Tarkiainen L. Heavy metal toxicity and mortality-association between density of heavy metal bands and cause specific hospital admissions and mortality: population based cohort study. BMJ 2021;375:e067633doi: 10.1136/bmj-2021-067633.

10 Franco JVA, Esteban S. Of research and robots: making sense of chance findings. BMJ 2021;375:n2915. doi: 10.1136/bmj.n2915

11 Harding E, Robinson P, Wilson J, Crutch SJ, Mummery CJ. Injections of hope: supporting participants in clinical trials. BMJ 2021;375:e066851.

12 Coleman E, Arundel C, Clark L, etal. Bah humbug! Association between sending Christmas cards to trial participants and trial retention: randomised study within a trial conducted simultaneously across eight host trials. BM 2021;375:e067742doi: 10.1136/bmj-2021-067742

13 Aggarwal P, Patel HP. Gatekeepers, wizards, and a mutual appreciation of each other's kingdoms. BMJ2021;375:n3005. doi: 10.1136/bmj.n3005

14 Rimmer A. Covid careers: how the pandemic changed my working life. BMJ 2021;375:n2762. doi: 10.1136/bmi.n2762 .

15 Hodgetts JM, Mohamed A, Lewis S. Just a smidge, or a bridge too far? Slang use in the ICU. BM/2021;375:e067900. doi: 10.1136/bmj-2021-067900

16 Feinmann J. The BMJ appeal 2021-22: "We can't turn women away"-providing maternity care under pressure in Afghanistan. BMJ 2021;375:n3004. doi: 10.1136/bmi.n3004 
17 Niederkrotenthaler T, Tran US, Gould M, etal. Association of Logic's hip hop song "1-800-273-8255" with Lifeline calls and suicides in the United States: interrupted time series analysis. BMJ 2021;375:e067726. doi: 10.1136/bmj-2021-067726.

18 Pitman A. A song of hope. BMJ 2021;375:n2964. doi: 10.1136/bmj.n2964

19 Macdonald H. The BMJ Interview: in conversation with Fiona Godlee. BMJ 2021;375:n2986. doi: 10.1136/bmj.n2986

20 Rimmer A. l'd like to thank ... BMJ 2021;375:n2816. doi: 10.1136/bmj.n2816 pmid: 34887287 